\title{
Free Speech at Work: Verbal Harassment as Discriminatory (Mis)treatment
}

Deborah Epstein

Georgetown University Law Center, epstein@law.georgetown.edu

This paper can be downloaded free of charge from:

https://scholarship.law.georgetown.edu/facpub/1709

http://ssrn.com/abstract=2805163

85 Geo. L.J. 649

This open-access article is brought to you by the Georgetown Law Library. Posted with permission of the author. Follow this and additional works at: https://scholarship.law.georgetown.edu/facpub

Part of the Law and Gender Commons, and the Sexuality and the Law Commons 


\section{Free Speech at Work: Verbal Harassment as Gender-Based Discriminatory (Mis)Treatment}

\section{DeBORAH EPSTEIN*}

In his reply to my article on workplace harassment law and freedom of speech, ${ }^{1}$ Professor Volokh does not respond to my most important critiques of his earlier work. For example, he fails to grapple with the true complexity of the problem by focusing exclusively on one side of this conflict of rights-the burden that the law imposes on workplace expression. Equal attention must be paid to the other side: the harm inflicted by discriminatory speech on employees of a single gender. As I describe in detail in my original piece, ${ }^{2}$ these harms may include: an adverse effect on the quantity and quality of a woman's ${ }^{3}$ work; emotional and physical stress-related problems such as fear, anxiety, depression, humiliation, nausea, fatigue, and headaches; and costs to the government of over $\$ 130$ million a year due to decreased worker productivity, sick leave awards, and replacement of employees who leave their jobs because of sexual harassment. ${ }^{4}$

Since my earlier article went to press, the papers have been bursting with horror stories about the differential (mis)treatment allegedly accorded to more than 500 women workers at the Mitsubishi plant in Normal, Illinois. Consider the harassing expression inflicted on just one of them-Sandra Rushing, who worked on the chassis line. Ms. Rushing was forced to deal with male coworkers who drew pictures of her engaged in sexual activities, labeled them with her name, and placed them on cars moving through the assembly line, where they would be seen by dozens of employees. On one occasion a male colleague exposed himself to her. Ms. Rushing complained to her supervisor, but things only got worse. One night, at the end of her shift, four male workers crowded around her, demanding that she have sex with them and telling her that if she

* Visiting Associate Professor, Georgetown University Law Center. J.D., New York University School of Law, 1988. I thank Michael Shuman, Freada Klein, and Susan Deller Ross for their helpful comments, and Barbra Marcus for her research assistance.

1. Eugene Volokh, What Speech Does "Hostile Environment" Harassment Law Restrict?, 85 GeO. L.J. 627 (1997).

2. Deborah Epstein, Can a "Dumb Ass Woman" Achieve Equality in the Workplace? Running the Gauntlet of Hostile Environment Harassing Speech, 84 GEO. L.J. 399, 402-08 (1996).

3. The vast majority of gender-based workplace harassment cases involve male harassers and female targets; for the sake of convenience I will use these gender roles here. Of course, situations do exist in which the roles are reversed.

4. See Epstein, supra note 2, at 403-08. The private sector also incurs high costs due to gender-based harassment. The average Fortune 500 company incurs sexual harassment costs of $\$ 6,700,000$ per year in absenteeism, low productivity, and employee turnover. This represents approximately $\$ 280$ per employee. Susan Crawford, Economic Impact of Sexual Harassment in the Workplace, USA TodAY (Magazine), Mar. 1, 1995, at 35 (citing 1988 Working Woman magazine survey, the "first scientific sampling of its kind in the private sector," based on responses of "directors of personnel, human resources, and equal-opportunity offices representing 3,300,000 employees at 160 corporations"). 
refused, they would force her to do so. Terrified, she ran to her car, crying and shaking. ${ }^{5}$ It is probable that Ms. Rushing, like hundreds of other women workers at Mitsubishi, was routinely called "slut," "whore," and "bitch." It is also likely that Ms. Rushing could not avoid seeing some of the many photographs depicting male employees and supervisors engaged in sexual activities with prostitutes at Mitsubishi-sponsored sex parties; the photos were placed in women's toolboxes and stacked in the plant's break rooms. ${ }^{7}$ Ms. Rushing's male colleagues, in contrast, were able to perform their jobs free of any analogous abusive expression. ${ }^{8}$

Disregarding the scope and severity of such discriminatory harm ${ }^{9}$ certainly makes Professor Volokh's case easier. But it also removes his arguments from the real-world aspects of the conflict and impairs his constitutional analysis.

Professor Volokh also fails to respond to my argument that workplace harassment law survives First Amendment strict scrutiny. This tripartite test, the most rigorous available under current constitutional doctrine and one that even the strongest and most vocal supporters of free expression applaud, should be used to resolve situations in which freedom of expression directly conflicts with another fundamental right - here, the Fourteenth Amendment right to equal protection of the law.

As I discuss in depth in my earlier article, ${ }^{10}$ restrictions on gender-based job harassment meet the first element of the test: they are supported by an interest strong enough to be deemed "compelling." In closely related contexts involving challenges to male-only membership policies in private clubs or sex-segregated publication of job advertisements, the Supreme Court has held that the elimination of marketplace gender discrimination is sufficiently compelling to justify restrictions on competing First Amendment rights. ${ }^{11}$ And the strength of the state's interest is heightened by the fact that Congress enacted Title VII ${ }^{12}$ in an express effort to carry out its constitutional obligation to enforce the Fourteenth Amendment's Equal Protection Clause. ${ }^{13}$

Current restrictions on verbal workplace harassment also meet the "neces-

5. Kirstin D. Grimsley et al., Sex Harassment: Tales of the Assembly Line; The Case Against Mitsubishi, INT'L Herald TrjB., May 3, 1996, at 6; Stuart Taylor, Jr., Closing Argument; Defining True Sexual Harassment, TEx. LAw., May 13, 1996, at 37.

6. Ellen Goodman, Harassment Battles Economics, MonTGOMERY ADVERTISER, May 6, 1996, at 8A.

7. Maria Shao, Mitsubishi Case Puts Spotlight on Harassment, Boston Globe, Apr. 28, 1996, at 1.

8. Nor were male workers subjected to the physical abuse that Ms. Rushing and many other female workers suffered. This included incidents in which male coworkers gathered around her, touching her breasts and reaching between her legs to touch her crotch. Taylor, supra note 5, at 37 .

9. See Epstein, supra note 2, at 402-08 (describing nature and severity of workplace harassment).

10. Id. at $436-42$.

11. See id. at $438-41$.

12. Although Title VII, 42 U.S.C. $\$ \S 2000$ e to e-17 (1994), does not expressly set forth a cause of action for workplace harassment, the Supreme Court has read one into the statutory bar on employment discrimination. See Harris v. Forklift Sys., Inc., 510 U.S. 17 (1993); Meritor Sav. Bank v. Vinson, 477 U.S. 57, 66-67 (1986).

13. See Epstein, supra note 2, at 436-37. 
sity" element of the strict scrutiny test. As the Mitsubishi case and others like it demonstrate, gender-based abusive expression can be quite severe; if it is allowed to continue unabated, the government will be unable to achieve its goal of eliminating employment discrimination. And the need for preventative regulation is underscored by the inability of the First Amendment marketplace of ideas to operate as an effective deterrent here; because of the power disparity between most harassers and their targets, women workers do not have a realistic opportunity to counter harassment by speaking out in favor of gender equality. In fact, studies show that most women are unable to stop or significantly reduce sexual harassment, whether verbal or physical, without filing an antidiscrimination lawsuit. ${ }^{14}$

Finally, restrictions on verbal harassment meet the third part of the strict scrutiny test because the law is as narrowly tailored as possible while remaining an effective tool for accomplishing the government's goal. Once a potential harasser leaves work, he is free to express any view he wishes. And he may do the same thing while on the job unless and until his target indicates that his speech is unwelcome.

But Professor Volokh does not discuss these issues; he focuses his reply on the fact that workplace harassment law can operate to restrict "political, artistic, religious, and socially themed speech," 15 rather than "only hard-core pornography, personal slurs, and repeated indecent propositions." 16 He fears that this problem is exacerbated by the risk that some employers, chilled by the threat of liability, may suppress isolated political statements that alone would not violate the law. ${ }^{17}$

I do not challenge these assertions. However, I do take issue with Professor Volokh's attempt to imbue them with a significance that is unsupported by First Amendment theory or doctrine.

In Part I of this article, I examine Professor Volokh's prioritization of political over nonpolitical, or "low value," speech and demonstrate that the creation of such a hierarchy of protection conflicts with the underlying values of the Free Speech Clause. In Part II, I consider the importance of context in the constitutional analysis of harassing speech and discuss how, by disregarding this factor, Professor Volokh distorts his analysis. In my earlier article, I examined genderbased harassing expression in terms of its physical context-the workplaceand its interpersonal context - the power disparity between harasser and target. Here, I focus on the general frailty of employees' free speech rights on the job. The weak nature of these rights, in contrast to the compelling government interest in promoting job equality, strengthens the argument that harassment law

14. See id. at $442-43$.

15. Volokh, supra note 1 , at 628 . I do not mean to imply that Professor Volokh concedes these points by deciding to disregard them. But by failing to take on the problem of verbal workplace harassment in its full complexity, he reduces the persuasive power of the argument he does make.

16. Id. at 627 .

17. Id. at $645-46$. 
survives First Amendment strict scrutiny. In Part III, I demonstrate that only a small chilling effect may be attributed to hostile environment harassment law. Much of the enormous chill that Professor Volokh posits is countered by the rigorous definitional requisites of a harassment claim. In addition, a large portion of the speech that harassment regulations could chill is already legally restricted by Title VII's ban on intentional discriminatory conduct. Finally, in the limited instances where employers are censoring speech by adopting draconian antiharassment policies, the law is not to blame; the problem stems from a dearth of sophisticated legal advice.

\section{Professor Volokh's Political/NonPolitical Hierarchy of Protected Expression Is a False Dichotomy That Threatens Fundamental Free Speech Values}

Professor Volokh argues that the constitutional failure of workplace harassment law derives primarily from its impact on what he dubs political or "core protected" speech. He does not define these terms, except to make clear that he uses "political" in a fairly broad sense, to include religious and social commentary as well as "legitimate" art. Although he is deeply concerned about the regulation of such expression, he posits that if workplace harassment law could be rewritten to immunize political speech, it would survive First Amendment challenge. ${ }^{18}$

I agree with Professor Volokh's assessment that a substantial amount of harassing workplace speech may be broadly characterized as political. When a person says, "There's nothing worse than having to work around women," 19 he is, at least in part, expressing a political view about gender roles in our society.

But how is this different when it comes to the kind of speech that Professor Volokh defines as nonpolitical and low in value, such as personal slurs, indecent propositions, and pornography? ${ }^{20}$ Most sexist slurs, whether personal or impersonal, convey political ideas about gender superiority and inferiority. ${ }^{21}$ Simi-

18. See id. As Volokh puts it at one point:

Of course, if the environment would have been abusive even without the political statements, a court could certainly say: "Setting aside the political statements, the other behavior-say, physical abuse and one-on-one personal slurs-was sufficiently severe or pervasive to constitute harassment." This would give the employee the relief he deserves, without basing it at all on the protected speech. The difficulties arise when the court makes clear that its decision was based ... [in part on] political statements.

Id. at 646 n.62. Volokh also asserts that if harassment law applied solely to nonpolitical, "low value" speech, "people's views" about its constitutionality "might be quite different." Id. at 1-2.

19. Robinson v. Jacksonville Shipyards, Inc., 760 F. Supp. 1486, 1498 (M.D. Fla. 1991).

20. See Volokh, supra note 1 , at 627,646 n.62.

21. "Objectionable and discredited as these ideas may be, they are ideas nonetheless." Nadine Strossen, Regulating Racist Speech on Campus: A Modest Proposal, 1990 DuKE L.J. 484, 549 (making related point in discussion of racist insults). 
larly, calling a female coworker a "cunt" 22 or a "dumb ass woman" 23 sends a strong political message about her relative lack of power in society, ${ }^{24}$ and many feminists believe that pornography communicates a "political-moral vision" about gender roles. $^{25}$

Perhaps the problem is most vividly illustrated by a comparison of the following two statements, made by a male police officer to a female colleague: (1) "Women can't make it as cops"; ${ }^{26}$ and (2) "You're a woman; you can't make it as a cop." Pursuant to Volokh's dichotomy, the former is a political statement about gender-based differences in physical ability and, accordingly, core protected speech that should not be subject to regulation. The latter is a nonpolitical personal slur, which may be suppressed with little cause for concern. This distinction is hardly a principled one. Should applicability of the Free Speech Clause turn on such an inconsequential difference in a speaker's turn of phrase? ${ }^{27}$

22. A review of gender-based hostile environment harassment cases reveals that an astonishing number of women workers are referred to as "cunts" by their supervisors or coworkers. This particular epithet is expressly cited in more than 20 federal cases that resulted in reported decisions; numerous additional claims must have been filed in cases that did not conclude with a published opinion, that came before state tribunals, or that settled out of court. The frequent use of this gender-based derogatory term is a graphic reminder of how words can contribute to the differential treatment of women on the job. The idea of an equivalently abusive, male-gendered epithet being hurled at men at a similar rate challenges the imagination.

Professor Volokh sanitizes the debate by avoiding the graphic language that riddles the case law. Although such language is disturbing, it is impossible to grasp the real-world situation facing women workers without confronting it. A few examples of the "cunt" cases follow: In Hurley v. Atlantic City Police Department, 933 F. Supp. 396 (D.N.J. 1996), police officer Donna Hurley's supervisor referred to her as "dumb cunt"; male colleagues regularly called women "cunts"; and coworkers placed a sexually graphic drawing of Ms. Hurley on the bathroom wall, accompanied by doggerel that began: "Oh sweet Donna Hurley/With cunt hair so curley [sic] ...." Id. at 402 n.2. Mary Carr, a female tinsmith apprentice, was subjected on a daily basis to comments such as, "I won't work with any cunt"; was continually referred to as "cunt"; found "cunt" painted on her toolbox; and received an obscene Valentine's Day card addressed to "Cunt." Carr v. General Motors Corp., 32 F.3d 1007, 1009 (7th Cir. 1994). Kim Balletti worked in a newspaper pressroom; her coworkers called her "fucking cunt" and placed a tube of vaginal cream labelled "Kim's Kunt Kreme" in her work station. Balletti v. Sun-Sentinel Co., 909 F. Supp. 1539, 1542-43 (S.D. Fla. 1995).

23. See Harris v. Forklift Sys., Inc., 510 U.S. 17, 19 (1993).

24. See Marcy Strauss, Sexist Speech in the Workplace, 25 HARv. C.R.-C.L. L. REv. 1, 25 (1990).

25. Michael J. Perry, Freedom of Expression: An Essay on Theory and Doctrine, 78 Nw. U. L. REV, 1137, 1182 (1984); see also Nadine Strossen, Defending Pornography 38 (1995); Nan D. Hunter \& Sylvia A. Law, Brief Amici Curiae of Feminist Anti-Censorship Taskforce, et al., in American Booksellers Association v. Hudnut, 21 MiCH. J.L. REFORM 69 (1987-88).

26. See DeAngelis v. El Paso Mun. Police Officers Ass'n, 51 F.3d 591, 595 (5th Cir.), cert. denied, 116 S. Ct. 473 (1995) ("Physically, the police broads just don't got it!").

27. Professor Volokh's "political speech" analysis is disserved by his method of pulling isolated statements from the case law and arguing that they illustrate the law's inappropriate suppression of core protected speech. The cases he cites fail to support his theory. As one example, Volokh states that a court found a hostile religious environment based in part on the fact that plaintiff was required "to suffer reference to the Holocaust by one of [his supervisors]." Volokh, supra note 1 , at 631 n.14 (internal quotation marks and parentheticals omitted). This sounds like a politically correct judge run amok. But consider the additional evidence offered by Deputy U.S. Marshal Robert Turner in support of his racial and religious discrimination claims: Turner was "only given limited access to the full range 
Moreover, Professor Volokh's apparent willingness to rely on a value-based hierarchy of expression, in which political speech receives priority, cannot be reconciled with a deep commitment to fundamental free speech values. ${ }^{28}$ "[A]11 attempts to create content-based subcategories [of expression] entail at least some risk that government will in fact be discriminating against disfavored points of view." 29 To frame the issue in Professor Volokh's own terms, who is to judge whether a particular instance of expression is low or high in value? The professor should heed his own advice: "[W]e can't judge [a rule] simply by how we would apply it ourselves. We must judge it by how we might expect it to be applied by the variety of fact-finders in our judicial system." 30

I prefer to start from the more speech-protective assumption that virtually all expression burdened by hostile work environment harassment law is political, or "high value." 31 This raises the next question: Is it possible to insulate

of duties and opportunities" of his job, and these restrictions (not placed on non-Jewish, non-white Marshals) harmed his efforts to obtain pay raises and promotions; he was denied a full opportunity to work overtime hours; was disciplined more harshly than his black colleagues; and was told to "get his white ass out of the office because this is a black office, for blacks, supervised by blacks." Turner $v$. Barr, 806 F. Supp. 1025, 1028 (D.D.C. 1992) (internal quotation marks omitted). Mr. Turner's black colleagues also made repeated derogatory comments about his religion. A supervisor told a Holocaust joke about how the high cost of Germany's post-World War II reconstruction was due to its substantial use of gas during the war; colleagues commented that it was appropriate for Mr. Turner to collect money for a charity drive, because Jews are skilled in dealing with money; and when he executed a writ at a jewelry store, coworkers commented that being a jeweller was something for Jews. Id. These facts are difficult to square with Professor Volokh's portrayal of this case as one that relied inappropriately on core protected speech.

Similarly, Volokh claims a court found a hostile environment based "largely" on "caricatures of naked men and women, animals with human genitalia" and a sexually explicit cartoon. Volokh, supra note 1, at 633 (internal quotation marks omitted). But in ruling that the plaintiff, Barbara Cardin, was subjected to illegal gender-based harassment, the court also relied on the following: a senior manager grabbed her by the buttocks in front of several of her coworkers; the company's general manager referred to women as "cunts"; the controller told Ms. Cardin that "all women are equal on their bellies"; and two senior managers widely disseminated a false rumor that Ms. Cardin was having an affair with another employee, causing her husband to leave her for several days. Cardin v. Via Tropical Fruits, Inc., No. 88-14201-CIV, 1993 U.S. Dist. LEXIS 16302, at *27 (S.D. Fla. July 9, 1993).

28. Even speech that Professor Volokh dubs "low value," such as obscenity, may be critically important to full and robust debate on a particular issue. In Professor Laurence Tribe's words:

[I]n the last analysis, suppression of the obscene persists because it tells us something about ourselves that some of us ... would prefer not to know. It threatens to explode our uneasy accommodation between sexual impulse and social custom-to destroy the carefully-spun social web holding sexuality in its place.... [T] The desire to preserve that web by shutting out the thoughts and impressions that challenge it cannot be squared with a constitutional commitment to openness of mind.

Laurence H. Tribe, American Constitutional Law § 12-16, at 919 (2d ed. 1988).

29. Id. § 12-18, at 940; see also STROSSEN, supra note 25, at 37-40, 50-54; Daniel A. Farber, Content Regulation and the First Amendment: A Revisionist View, 68 Geo. L.J. 727 (1980); Kenneth L. Karst, Equality as a Central Concept in the First Amendment, 43 U. CHI. L. Rev. 20 (1975); Martin H. Redish, The Content Distinction in First Amendment Analysis, 34 StaN. L. Rev. 113 (1981); Geoffrey R. Stone, Restrictions of Speech Because of Its Content: The Peculiar Case of Subject-Matter Restrictions, $46 \mathrm{U}$. CHI. L. Rev. 81 (1978).

30. Volokh, supra note 1 , at 634-35.

31. Of course, one would be hard-pressed to characterize as political many of the statements that 
gender-based discriminatory speech from regulation simply by labeling it political?

\section{First Amendment Analysis of Expression, Whether Political or Otherwise, Cannot OCCur in a Contextual VacuUm}

In Professor Volokh's view, political speech is "core protected"-end of discussion. But this constitutional analysis occurs in a contextual vacuum; he does not address the complex relationship between the content and context of expression that is integral to modern First Amendment jurisprudence. Although many theorists agree that the inherent social value of political expression justifies special concern about its protection, ${ }^{32}$ the Constitution clearly permits the government to regulate it in a wide range of circumstances.

For example, although the slogan "Abortion makes you the mother of a dead baby" 33 is a political statement, the right to shout it varies depending on whether the speaker is in a public park or on the premises of an abortion clinic, where the targeted audience is captive and has no realistic way to avoid the speech. ${ }^{34}$ Similarly, the government may prohibit focused picketing at an individual's residence, even if the picket is conducted by anti-abortion activists bearing political placards and the home is one of a doctor who performs abortions. ${ }^{35}$ A statement that defames a public official may well constitute political commentary, but it is against the law if said with reckless disregard for its truth or falsity. "I' but if spoken seriously, it is punishable as a criminal threat. ${ }^{37}$ Put simply, political speech can claim no talismanic immunity from regulation. ${ }^{38}$

have contributed to the existence of a hostile work environment. For example, receptionist Judith Jones's employer told her that someday her breasts would be his; he also said she should spend more time in the kitchen, where the temperature was lower and he could see her nipples better. Jones $v$. Wesco Invs., 846 F.2d 1154, 1155 (8th Cir. 1988). While Leta Fay Ford worked as a buyer for Revlon, her supervisor repeatedly told her, "I want to fuck you. I am going to fuck you." Ford v. Revlon, 734 P.2d 580, 582 (Ariz. 1987). And when police sergeant Donna Hurley couldn't find her coffee mug, a male coworker asked her "if she wanted to drink out of his jock cup." Hurley v. Atlantic City Police Dep't, 933 F. Supp. 396, 406 (D.N.J. 1996).

32. See, e.g., Alexander Meiklejohn, Political Freedom (1960); Alexander Meiklejohn, Free SPEECH AND ItS RELATION TO SELF-GOVERNMENT (1948).

33. Darrel Rowland, Though Kept at Bay, Critics Get Their Say, Columbus Dispatch, Aug. 13, 1996 , at $5 \mathrm{~A}$ (quoting anti-abortion protesters).

34. See Madsen v. Women's Health Ctr., Inc., 512 U.S. 753 (1994); Epstein, supra note 2, at 421-29.

35. See Frisby v. Schultz, 487 U.S. 474 (1988).

36. See New York Times Co. v. Sullivan, 376 U.S. 254 (1964).

37. See, e.g., Watts v. United States, 394 U.S. 705 (1969). In Watts, the Court upheld the constitutionality of a statute criminalizing willful threats on the life of the President. If such statements were made as part of a stand-up comedy routine, however, they might be in bad taste, but the speaker would be immune from punishment. See id. at 705 (overturning conviction of individual who stated that if ever inducted into the army, "the first man I want to get in my sights is L.B.J.," on grounds that context demonstrated statement was hyperbole protected by First Amendment).

38. Context plays an equally important role in determining the state's ability to regulate what Volokh would call nonpolitical speech. If any part of the "fighting words" doctrine survives, it is tightly bound by a contextual framework: the speech must be made in the midst of a face-to-face confrontation in 
The free speech rights of harassers are no different; they are limited by the contextual constraints of the workplace. My original article contains an extensive analysis of the First Amendment implications of two fundamental contextual issues that are directly relevant here. First, what is the physical location where harassing expression occurs, and to what extent is a targeted worker either captive to it or able to avoid it? Second, what is the interpersonal context, and to what extent does the power disparity between harassers and targeted workers contribute to a target's captivity and restrict her freedom to respond? $?^{39}$

I will not repeat that discussion here. But another aspect of the context issue needs to be explored: How strong are workers' First Amendment rights while they are on the job? ${ }^{40}$

I am sympathetic to a person's desire to express himself at work, where he probably spends a sizable portion of his waking hours. But the free speech rights of employees in the workplace are weak at best; as a general rule they must obey their employer's edicts about what they can and cannot say. In the private sector, for example, no general principle of freedom of expression exists at all. An at-will employee can be fired for almost any reason (or no reason), including his decision to call female coworkers "cavern cunts," ${ }^{41}$ or to tell his

which it is likely to provoke the listener to violence. See Gooding v. Wilson, 405 U.S. 518, 523 (1972); Cohen v. California, 403 U.S. 15, 20 (1971). As Professor Greenawalt puts it, "Forms of expression vary so much in their contexts and inflections that one cannot specify particular words or phrases as always being 'fighting.' What is gross insult in one setting is crude humor in another." Kent Greenawalt, Speech and Crime, 1980 AM. B. Found. RES. J. 645, 770. Similarly, even the kind of speech that the Court values least—obscenity-must be measured in the context of changing contemporary community standards. See, e.g., Miller v. California, 413 U.S. 15, 24 (1973).

39. Epstein, supra note 2, at 420-33.

40. Professor Volokh claims to be "puzzled" by my assertions that the reach of workplace harassment law is generally limited to the physical location of the job site, and that I was unable to locate any post-Vinson case in which a court relied on speech outside the worksite to support a finding of hostile environment. He states that he was able to find contradictory cases with ease. But the cases he cites do not support his proposition.

Professor Volokh asserts that in Bersie v. Zycad Corp., 399 N.W.2d 141 (Minn. Ct. App. 1987), the court "rel[ied] in part on a coworker calling [Bersie] at home" in "applying Vinson." Volokh, supra note 1, at 629 n.6 (internal quotation marks omitted). It is true that the court's recitation of "Facts" includes an incident in which one of Ms. Bersie's coworkers called her at home and "goaded her about her absence from work"; but the court never references this fact in its "Analysis" section, in which it considers whether a hostile environment existed. Professor Volokh's claim that this opinion demonstrates the court's "reliance" on the call at home is insupportable; one might just as well claim that the court relied on its recitation of the fact that Ms. Bersie was a "39-year-old mother of two." Bersie, 399 N.W.2d at 142. Volokh's point is undermined even further by the fact that the court later ruled against Ms. Bersie, holding that no hostile environment existed. Bersie v. Zycad Corp., 417 N.W.2d 288, 290 (Minn. Ct. App. 1987).

Professor Volokh also cites Bartlett v. United States, 835 F. Supp. 1246 (E.D. Wash. 1993), for its failure to "even hint]" that a sexually explicit card which plaintiff received at home could not support a hostile work environment. Volokh, supra note 1, at 629 n.6. But the court's analysis consists of a single sentence in which it concludes that the evidence is "insufficient, as a matter of law, to establish a sexual harassment or hostile environment claim." Bartlett, 835 F. Supp. at 1262. Professor Volokh may believe that the court should have engaged in a more detailed analysis, but he can hardly claim that this opinion supports the use of extraworkplace incidents as a basis for a Title VII harassment claim.

41. See Hall v. Gus Constr. Co., 842 F.2d 1010, 1012 (8th Cir. 1988). 
female supervisees that they should dress in a way that exposes their breasts. ${ }^{42}$ Even in the public sector, where the First Amendment applies in a limited sense, employees can be fired for speech that is unrelated to matters of public concern or that disrupts workplace efficiency or harmony. ${ }^{43}$ The limited scope of a worker's right to speak freely on the job has long been justified on the ground that although such speech is valuable and important, the workplace is not designed as a forum for employees to "discuss matters of great importance to themselves, perhaps to society as a whole, but not to the employer." 44 After all, in the words of the Seventh Circuit, "the workplace is for working." 45

The discrete areas in which employee speech has been singled out for special protection only highlight the general absence of First Amendment limits on employer control. For example, several statutes now prohibit employer retaliation against whistleblowing employees who make complaints or participate in regulatory proceedings. ${ }^{46}$ Previously, even this kind of worker speech, which provides crucial information about safety and security concerns, was vulnerable to suppression and could be grounds for dismissal.

Even employers have limited rights of expression on the job. For example, an employer cannot engage in speech that could unfairly interfere with a union election. ${ }^{47}$ This restriction on employer expression is justified by the state's interest in ensuring the adequate protection of workers' rights. ${ }^{48} \mathrm{~A}$ similar logic may be applied to sexual harassment law; its restriction on workplace expression is justified by the state's interest in preventing gender-based employment discrimination. ${ }^{49}$

Professor Volokh's approach to the problem appears to turn Title VII, a civil rights statute designed to eradicate the serious social problem of employment discrimination, into a vehicle for converting the workplace into a First Amendment sanctuary. Before the statute was enacted, an employer certainly could fire someone for constantly referring to female employees as "dumb ass women" while treating their male counterparts in a respectful, professional manner.

42. See Harris v. Forklift Sys., Inc., 510 U.S. 17, 19 (1993).

43. See Rankin v. McPherson, 483 U.S. 378, 388 (1987) (recognizing "the interest of the State, as an employer, in promoting the efficiency of the public services it performs through its employees"); Connick v. Myers, 461 U.S. 138 (1983); Pickering v. Board of Educ., 391 U.S. 563, 568 (1968); see also Waters v. Churchill, 511 U.S. 661 (1994).

44. May v. Evansville-Vanderburgh Sch. Corp., 787 F.2d 1105, 1110 (7th Cir. 1986).

45. Id.

46. See, e.g., Whistleblower Protection Act, 5 U.S.C. § 2302 (1994) (prohibiting employer retaliation against federal employees who report fraud or abuse); National Labor Relations Act, 29 U.S.C. \$ 158(a)(4) (1994) (prohibiting employer retaliation against employees who file charges or testify under the Act); Occupational Safety and Health Act, 29 U.S.C. § 660(c) (1994) (prohibiting employer retaliation against employees who report violations of safety standards); Employee Retirement Income Security Act, 29 U.S.C. $\$ \S 1140-41$ (1994) (prohibiting employer retaliation against employees claiming benefits under the $A c t$ ).

47. NLRB v. Gissel Packing Co., 395 U.S. 575 (1969); NLRB v. Exchange Parts Co., 375 U.S. 405 (1964).

48. See Epstein, supra note 2, at 429-33.

49. Id. at $436-50$. 
Professor Volokh's theory would insulate this speaker from punishment, even when the speaker's gender-based, abusive pattern of expression takes such a toll that it forces women out of their jobs. Although I support the expansion of workers' rights, this seems to be an odd place from which to start. As Professor Suzanne Sangree puts it, "While cogent arguments can be made for empowering workers and democratizing the American workplace, [a desire to protect those who discriminate] is not one of them." 50

\section{The Limited Scope of Harassment Law's True ChILling Effect}

Professor Volokh also argues that hostile environment harassment law has an enormous chilling effect on workplace expression. He recognizes that the law imposes liability only when harassment is directed at its target on the basis of her gender and is sufficiently severe or pervasive to alter the terms or conditions of a reasonable target's employment, thereby creating an abusive work environment. ${ }^{51}$ But he claims that " '[s]evere,' 'pervasive,' 'hostile,' and 'abusive' are mushy terms"; they are "too vague to provide much protection for speech." 52 But are these terms any more vague than others used in well-settled areas of constitutional jurisprudence? For example, expression constitutes defamation of a public official only if it is shown to have been uttered with "reckless disregard" for its truth or falsehood. ${ }^{53}$ It would be difficult to demonstrate that this term is substantially more clear and precise than are the terms "severe" and "pervasive."

But I certainly concede that workplace harassment law will result in the suppression of some speech that lies beyond its intended scope. That is the case with every regulation that affects expression. The extent of this "chill," however, is far less significant than Professor Volokh fears or the Constitution prohibits.

As I have pointed out elsewhere,${ }^{54}$ much of the speech that hostile environment restrictions could chill is already legally regulated. For example, even if all of harassment law were invalidated, Title VII's prohibition on intentional discriminatory conduct would continue to provide an incentive for employers to

50. Suzanne Sangree, A Reply to Professors Volokh and Browne, 47 RuTGERS L. Rev. 595, 603 (1995). Historically, the Free Speech Clause has been portrayed as a vehicle for protecting minority views against a powerful and intolerant majority; it has been touted for its role in increasing individual autonomy and democracy by promoting the speech of the vulnerable. But limiting Title VII's ban on gender-based abusive speech will not accomplish this goal. Instead, it will protect the speech of the powerful dominant group in the workplace (white men) and leave women and minority workers even more defenseless.

51. Volokh, supra note 1, at 627-28. Professor Volokh's definition omits other essential elements of a hostile environment harassment claim, including: (1) the harassment must be unwelcome to the target, and this unwelcomeness must be communicated to the harasser; and (2) the employer must perpetrate or condone the harassment. See Epstein, supra note 2, at 412-14. The impact of these omissions on Professor Volokh's analysis is discussed infra text accompanying notes 77-84.

52. Volokh, supra note 1, at 634, 638 (internal quotation marks omitted).

53. New York Times Co. v. Sullivan, 376 U.S. 254, 279-80 (1964).

54. Epstein, supra note 2, at 419. 
suppress gender-based abusive speech. Such statements constitute the most common form of evidence that plaintiffs offer to prove that decisions to hire or fire were made with discriminatory intent. The Supreme Court has firmly decided that evidence admissible for this purpose includes expression. ${ }^{55}$

In intentional discrimination cases, gender-based abusive or sexual statements, when made or tolerated by management, are particularly probative because of the inherent difficulty of proving state of mind. Given that "[d]efendants of even minimal sophistication will neither admit discriminatory animus nor leave a paper trail demonstrating it," plaintiffs typically must rely on circumstantial evidence of their employers' intent. ${ }^{56}$ The courts consistently have held that a wide range of indirect evidence is admissible to prove intenteven evidence that in other situations might be excluded as irrelevant or more prejudicial than probative. ${ }^{57}$

For example, in Price Waterhouse v. Hopkins, ${ }^{58}$ a female accountant who was denied partnership sued her firm for intentional discrimination on the basis of gender. At trial, she introduced into evidence a partner's repeated statements that "he could not consider any woman seriously as a partnership candidate and believed that women were not even capable of functioning as senior managers." 59 The Supreme Court found in Ms. Hopkins's favor, relying in part on these gender-based derogatory comments. ${ }^{60}$

Professor Volokh disputes the significance of this point, arguing that harassment law "covers much more speech than the kind that's likely to be used as evidence of discriminatory animus in employment decisions." ${ }^{61}$ Specifically, he claims that illegal intent can be proven only through the speech of supervisors, and only if it directly relates to the employment decision. ${ }^{62}$ But the case law contradicts these assertions.

55. See id. The First Amendment "does not prohibit the evidentiary use of speech ... to prove motive or intent. Evidence of a defendant's previous declarations or statements is commonly admitted in ... trials subject to evidentiary rules dealing with relevancy, reliability, and the like." Wisconsin $v$. Mitchell, 508 U.S. 476, 489 (1993).

56. Riordan v. Kempiners, 831 F.2d 690, 697 (7th Cir. 1987).

57. See, e.g., id. at 697-98. As one court noted,

Circumstantial proof of discrimination typically includes unflattering testimony about the employer's history and work practices-evidence which in other kinds of cases may well unfairly prejudice the jury against the defendant. In discrimination cases, however, such background evidence may be critical for the jury's assessment of whether a given employer was more likely than not to have acted from an unlawful motive.

Estes v. Dick Smith Ford, Inc., 856 F.2d 1097, 1103 (8th Cir. 1988).

58. 490 U.S. 228 (1989).

59. Id. at 236 .

60. Id. at 236, 256-58; see also Tomsic v. State Farm Mut. Auto. Ins. Co., 85 F.3d 1472 (10th Cir. 1996) (supervisor's comments about one plaintiff lacking incentive to work hard because her husband made too much money and another plaintiff risking potential marital problems because soon she would be earning more than her husband held admissible as indirect evidence of employer's intent to terminate plaintiffs on basis of gender).

61. Volokh, supra note 1, at 638 n.34.

62. See id. 
First, the speech of coworkers as well as supervisors repeatedly has been held to constitute indirect evidence of an employer's intent in cases based on discriminatory conduct. In Samarzia v. Clark County ${ }^{63}$ for example, the Ninth Circuit held that coworkers' references to the plaintiff as "senile" constituted relevant circumstantial evidence that his termination was the result of age discrimination. ${ }^{64}$ The Eighth Circuit has arrived at the same conclusion based on a slightly different theory. In Tart v. Hill Behan Lumber Co. ${ }^{65}$ a race-based discriminatory discharge case, the plaintiff testified that white coworkers subjected him and other black employees to racial slurs, and that when the abusive language was reported to a supervisor, the supervisor failed to take any corrective action. The court approved admission of this testimony into evidence, holding that an employer's tolerance of racist speech by coworkers tended to show the existence of a discriminatory motive. ${ }^{66}$

Second, speech need not be directly related to a challenged employment decision to be admitted as proof of illegal intent. A female teacher claiming discriminatory termination may prove impermissible motive through evidence of student harassment claims that have been filed against the school. ${ }^{67} \mathrm{~A}$ supervisor's comments about female employees, including the size of their breasts, the way they walk, and the way they move, have been deemed indicative of his gender-biased motive in firing another woman worker. ${ }^{68}$ And evidence that a supervisor occasionally directed racial slurs at the plaintiff and other black employees "is certainly probative" of a race-based discriminatory discharge claim. ${ }^{69}$

63. 859 F.2d 88 (9th Cir. 1988).

64. Id. at 91-92. Plaintiff offered other forms of indirect evidence as well, including discriminatory statements made and actions taken by his supervisors. The court did not determine whether the proof plaintiff adduced was sufficient to prove discriminatory intent but held that it was relevant and admissible, and for this reason it reversed the trial court's directed verdict for the defendants. Id.; see also Blake v. J.C. Penney Co., 894 F.2d 274, 276-78 (8th Cir. 1990) (coworkers calling plaintiff "senile old woman" and "senile old thing" held to be admissible evidence of discriminatory motive in age-based termination claim where employer tolerated such insults).

65. 31 F.3d 668 (8th Cir. 1994).

66. Id. at 673-74; see also Glass v. Philadelphia Elec. Co., 34 F.3d 188 (3d Cir. 1994); Mullen v. Princess Anne Volunteer Fire Co., 853 F.2d 1130 (4th Cir. 1988); Lincoln v. Board of Regents, 697 F.2d 928 (11th Cir.), cert. denied, 464 U.S. 826 (1983); O’Keefe v. General Accident Ins. Co., 918 F. Supp. 115 (S.D.N.Y. 1996); Woodson v. Scott Paper Co., 898 F. Supp. 298 (E.D. Pa. 1995); Pakizegi v. First Nat'l Bank of Boston, 831 F. Supp. 901 (D. Mass. 1993), aff'd without opinion, 56 F.3d 59 (1st Cir. 1995).

67. Hawkins v. Hennepin Technical Ctr., 900 F.2d 153 (8th Cir.), cert. denied, 498 U.S. 854 (1990).

68. EEOC v. Farmer Bros. Co., 31 F.3d 891 (9th Cir. 1994). Similarly, in Heyne v. Caruso, 69 F.3d 1475 (9th Cir. 1995), the court held that evidence of an employer's unwelcome sexual behavior toward several female employees was relevant to the issue of intent in another woman worker's quid pro quo harassment case. Id. at 1479-81; see also Sowers v. Kemira, Inc., 701 F. Supp. 809 (S.D. Ga. 1988) (same).

69. Estes v. Dick Smith Ford, Inc., 856 F.2d 1097 (8th Cir. 1988); see also Antol v. Perry, 82 F.3d 1291 (3d Cir. 1996) (disability discrimination case); Hawkins, 900 F.2d at 153 (holding that evidence of harassment of other female employees admissible to prove gender-based disparate treatment and retaliation claim); Spulak v. K-Mart Corp., 894 F.2d 1150, 1155 (10th Cir. 1990) (holding that supervisor's comment, "these old fogies are either going to have to comply or get out," although made 
Professor Volokh further argues that it "seems unlikely ... that a court would admit evidence of sexually themed jokes or sexually suggestive pictures ... to show that management was motivated by animus when firing an employee."70 But this is not the case. The courts have admitted closely related types of evidence for exactly this purpose, including: jokes about how a female employee's husband "must love [her] big bazooms";" racist jokes with the punch line, "May all your babies be white";" jokes that hiring a woman judge meant taking her "out of the kitchen, tak[ing] her apron off, and put[ting] a robe on her"; ${ }^{73}$ "hostile and demeaning images" of the plaintiff posted by coworkers; ${ }^{74}$ and even photographs of the Ayatollah Khomeini and an American flag burning in Iran, both posted by a coworker in her own cubicle. ${ }^{75}$

Thus, contrary to Professor Volokh's assertion, speech that tends to show discriminatory intent in conduct cases is often precisely the kind of speech that might be chilled by harassment law. Overturning hostile environment harass-

to an employee other than plaintiff, relevant to prove intent in age discrimination case); Williams $\mathrm{v}$. McCausland, No. 90-CIV.7563, 1995 WL 548862, at *32 (S.D.N.Y. Sept. 15, 1995) (race discrimination case may be proved through employer's invidious comments about others in the employee's protected group).

Neither of the two cases cited by Professor Volokh contradicts this principle. In Fuka v. Thomson Consumer Elecs., 82 F.3d 1397 (7th Cir. 1996), although the court held that plaintiff's evidence about her supervisor's age-based remarks was insufficient to demonstrate discriminatory intent, it expressly stated that if "considered in conjunction with other evidence, [the statements] could support an inference of discrimination." Id. at 1404; see also Cone v. Longmont United Hosp. Ass'n, 14 F.3d 526, 530 (10th Cir. 1994) (age-based remarks considered as potentially probative of discriminatory intent). So long as gender-, race-, and age-based comments are probative in determining the existence of discriminatory animus in a disparate treatment case, an incentive to chill such speech will continue to exist. This incentive does not evaporate merely because, in some subset of weak cases, these statements alone are insufficient to constitute conclusive proof of motive.

70. Volokh, supra note 1 , at 638 n.34.

71. EEOC v. Northwestern Memorial Hosp., 858 F. Supp. 759, 766 (N.D. Ill. 1994).

72. Taylor v. Western \& S. Life Ins. Co., 966 F.2d 1188, 1191 (7th Cir. 1992).

73. Goodwin v. Circuit Court, 729 F.2d 541, 544 (8th Cir. 1984).

74. Glass v. Philadelphia Elec. Co., 34 F.3d 188, 192 (3d Cir. 1994).

75. Pakizegi v. First Nat'l Bank of Boston, 831 F. Supp. 901 (D. Mass. 1993), aff'd without opinion, 56 F.3d 59 (1st Cir. 1995). In Pakizegi, the court allowed an Iranian plaintiff to submit evidence of two photographs that a coworker had posted in her own cubicle, one of the Ayatollah Khomeini and one of an American flag burning in Iran, in an attempt to demonstrate that plaintiff's termination was based on her national origin. Although the court ruled against plaintiff on this claim, the mere fact that the photographs were admitted into evidence creates the potential for a chilling effect on similar employee expression.

Professor Volokh cites this case for an entirely different proposition-one for which it does not stand. He asserts that the court characterized the two photographs as national-origin harassment of an Iranian plaintiff. Volokh, supra note 1 , at 632 . But the case isn't a harassment case at all. Instead, the plaintiff claimed that she was illegally fired on the basis of her national origin and, even more significantly, she lost-the court granted summary judgment in the employer's favor. Pakizegi, 831 F. Supp. at 908. Professor Volokh makes similar misstatements elsewhere. For example, he claims that a court found that the "use of job titles such as 'foreman' and 'draftsman' may constitute sexual harassment." Volokh, supra note 1, at 631. But the court not only ruled against the plaintiff, finding that no discrimination had occurred, it also expressly noted that " $[t]$ he use of gender-based language and terminology shown in this record does not constitute a Title VII violation." Tunis v. Corning Glass Works, 747 F. Supp. 951, 958 (S.D.N.Y. 1990) (emphasis added), aff'd without opinion, 930 F.2d 910 (2d Cir. 1991). 
ment restrictions alone will not free employers from pressure to prohibit such expression. $^{76}$

Of course, it is possible that a few employers will not regulate worker speech solely to avoid liability for intentional discrimination but will do so out of fear of facing a harassment claim. And there may be a small universe of genderbased abusive or sexual speech that could be chilled by harassment law but could not support an inference of intentional discrimination-perhaps the occasional, mild, gender-based remark. But on the whole, when viewed in the broader Title VII context, the incremental chilling effect directly attributable to hostile environment harassment law is a relatively small one.

Professor Volokh also argues that because a hostile environment may be created through the aggregation of numerous individual statements, "prudent, law-abiding employers" have no realistic choice but to adopt a "zero-tolerance policy" and suppress all gender-based abusive or sexual speech. ${ }^{77}$ But such an extreme response is far from inevitable; Professor Volokh only reaches this conclusion by failing to consider several essential elements of a hostile environment claim, thus defining actionable harassment far more broadly than does the Supreme Court. In fact, hostile environment harassment law places careful limits on employers' liability exposure, permitting the adoption of more moderate speech-protective policies.

First, the law dictates that an employer cannot be held liable for harassing speech or conduct unless and until the target clearly indicates that she does not welcome it. ${ }^{78}$ Accordingly, an employer need not forbid all sexual or genderbased abusive speech; instead, he may explain to workers that they may make such comments until they receive an indication that a target finds them undesirable. Employers can provide training on how to recognize expressions of unwelcomeness, including the possibility that in some circumstances silence may be an indicator, and can further suggest that if a female employee's response is unclear, the best strategy is to ask how she feels. By training male and female employees to better understand each other, an employer may effectively avert those harassment claims that arise out of miscommunication without engaging in absolutist censorship.

Second, a plaintiff cannot prevail unless she proves not only that she finds her

76. Professor Volokh exaggerates the conclusion that I draw from this overlap in the incentive to chill gender-based harassing speech. He implies that in situations in which some degree of chilling effect is inevitable, I would advocate eliminating any limitations that could exist. He chastises me for taking such an extremist position, pointing out that "the fact that we must tolerate some chilling of speech doesn't demonstrate that we should tolerate more." Volokh, supra note 1, at 638 n.34.

But of course, I agree with him and firmly believe in the fundamental importance of cabining any chilling effect that a law has on expression. I am merely attempting to pinpoint the precise extent to which a chill may be attributed to workplace harassment law. My efforts to define the true scope of the problem are intended to enhance, not impede, our ability to grapple with it.

77. See id. at 638,648 and passim.

78. Meritor Sav. Bank v. Vinson, 477 U.S. 57, 68 (1986); Epstein, supra note 2, at 413-14. 
environment to be hostile, but also that a reasonable person would agree with her. ${ }^{79}$ By demanding reasonableness, the law assures employers that they need not use the fragile sensibilities of a hypersensitive listener as a regulatory gauge. ${ }^{80}$

Third, a plaintiff must show that the harassment is either severe or pervasive. ${ }^{81}$ The required showing of severity varies inversely with the pervasiveness of the abuse; because verbal harassment is inherently less severe than its physical counterpart, it will be actionable only in extreme situations when it saturates a target's work environment. This legal requirement therefore prohibits the imposition of liability for a few stray remarks and makes it unnecessary to overcensor.

Finally, no employer can be held liable unless and until it receives legally adequate notice of the problem. ${ }^{82}$ Even then, the employer's sole obligation is to respond by investigating and, if necessary, by taking action to stop the harassment. The case law interpreting this requirement demonstrates that an employer need not overcensor; instead, it may ensure that a victim-friendly grievance procedure exists and workers are encouraged to report immediately any incidents that they consider harassing. An employer who takes these steps has fully discharged its legal obligation. ${ }^{83}$

All of the above requirements operate together to ensure that by educating workers about the scope of hostile work environment harassment law, training them to improve interpersonal communication, and creating grievance procedures that allow effective evaluation of and response to harassment complaints, an employer can protect itself from liability whịle allowing workers breathing room for expression. ${ }^{84}$

Of course, as Professor Volokh suggests, an employer may find it easier to avoid such calculations by adopting an overzealous zero-tolerance antiharassment policy. But because hostile environment harassment restrictions carefully carve out room for less draconian approaches, such behavior is not attributable to the law's chilling effect, but instead to a dearth of sophisticated legal advice.

79. Harris v. Forklift Sys., Inc., 510 U.S. 17, 21 (1993); Epstein, supra note 2, at 414-15.

80. See Harris, 510 U.S. at 21; Epstein, supra note 2, at 414-15.

81. Vinson, 477 U.S. at 67; Epstein, supra note 2, at 412.

82. See Epstein, supra note 2, at 412.

83. See id.

84. Professor Volokh is incorrect when he suggests that such an approach, like the one I proposed in my original article, would necessarily abolish the law's "severe or pervasive" requirement. He describes my earlier proposal as a speech-restrictive policy under which "[e]mployees can . . only say gender-specific or sexual things ... until one listener objects. At that point, they must either shut up or schedule a meeting with a designated EEO officer before speaking further." Volokh, supra note 1, at 637 (internal quotation marks and emphasis omitted). But employees need not "shut up" at this point. They may continue to engage in, look at, or post gender-based abusive expression: (1) in the presence of anyone at all, off the job site; (2) in the presence of other workers who have not indicated an unwillingness to listen; (3) in places within the worksite that are truly private and where the unwilling listener would not be captive to it, such as a private locker or toolbox; and (4) in the presence of workers who have indicated that the expression is unwelcome, if the EEO officer determines that the speech does not violate the law. By protecting against employment discrimination while minimizing the detrimental impact on speech, this kind of policy represents the best compromise possible-particularly given the compelling need for workplace equality and the frailty of workplace free speech rights. 
And while I share Professor Volokh's concern that many consultants are encouraging employers to adopt overbroad antiharassment policies and that some employers are acting on such advice, many others are declining to do so. ${ }^{85}$ As I have described elsewhere, ${ }^{86}$ if employers were overregulating and only disobedient workers were engaging in harassing speech, increasing numbers of employers should be asserting their speech-restrictive antiharassment policies as a defense to liability. But no evidence of such an increase exists.

Freada Klein, one of the best-known employer consultants in the field, reports that once employers think through the real-life ramifications of extremist policies, they quickly realize that "no business can or wants to live by" them. ${ }^{87}$ If a policy prohibits all physical contact, what happens when a secretary learns of a death in her family and her boss of ten years wants to give her a comforting hug? If a policy prohibits all requests for dates, what happens when two employees meet at a company picnic, fall madly in love, and want to begin a relationship?

Most employers recognize that an absolutist policy forbidding such interactions could have a devastating impact on employee morale, which in turn could adversely affect the business's bottom line. A large body of management literature demonstrates the close relationship between these two factors. ${ }^{88}$ For example, companies have found that by adopting morale-boosting work-family initiatives such as on-site child care, jobsharing, and flex time, they can attract higher-quality workers, reduce employee absenteeism and turnover, improve client retention rates, and dramatically increase their profit margins. ${ }^{89}$ These companies understand that they lose a competitive advantage when they harm worker morale and that adopting a moderate, practicable approach to workplace harassment is less costly than overreacting.

Many of these employers are providing breathing room for sexual speech and conduct by creating informal complaint procedures for harassment victims as an alternative to formal reporting. ${ }^{90} \mathrm{~A}$ worker who believes herself to be a target of harassment may consult in strict confidentiality with an ombudsperson, whose position lies outside of the company's regular reporting channels. The ombudsperson may offer the employee counseling, mediation, or other informal assistance

85. Telephone Interview with Freada Klein, President of Klein Associates, Inc. (Aug. 22, 1996) [hereinafter Klein Interview]. Similarly, the law's 10-year enforcement record in the judicial system demonstrates that the primary danger is not the one feared by Professor Volokh-overbroad enforcement-but the opposite: it is enforced too narrowly. The courts routinely apply a constricted interpretation of the severe or pervasive requirement in hostile environment harassment cases. See Epstein, supra note 2, at 415-18 (discussing evidence of courts' narrow approach to employer liability in these cases).

86. Epstein, supra note 2, at 418.

87. Klein Interview, supra note 85 .

88. See, e.g., Keith H. Hammonds, Balancing Work and Family: Big Returns for Companies Willing to Give Family Strategies a Chance, Bus. WK., Sept. 16, 1996, at 74; Fran S. Rodgers \& Charles Rodgers, Business and the Facts of Family Life, Harv. Bus. Rev., Nov.-Dec. 1989, at 121.

89. See, e.g., Hammonds, supra note 88.

90. A complainant may choose to pursue either one or both of these options. 
without exposing the harasser to censure or "chill." 91 As this more nuanced approach illustrates, the problem of extremist policies does not lie with the law itself, but rather with consultants who are offering employers an easy but unnecessarily speech-restrictive way out.

And those employers who are adopting draconian antiharassment policies are not enforcing them. Ever-increasing numbers of sexual harassment suits are being filed and a vast body of data demonstrates that most female employees continue to be subjected to unwelcome gender-based abusive or sexual speech. ${ }^{92}$

Indeed, the real "chill" in the sexual harassment arena is not experienced by harassers, but by complainants. Only a small percentage of workers who believe they have experienced sexual harassment actually report the abuse to their employers. ${ }^{93}$ Victims cite fear of reprisal as a key reason for their failure to come forward. ${ }^{94}$ Their concern is well-founded; one study reveals that twentyfour percent of victims surveyed were fired because they complained about sexual harassment. ${ }^{95}$

For all of these reasons, hostile environment harassment law's potential chilling effect on harassing expression is narrowly limited. This fact, viewed in conjunction with the frailty of workers' free speech rights on the job ${ }^{96}$ as well as additional contextual factors discussed in my earlier article, ${ }^{97}$ demonstrates that the law presents no constitutional violation.

But let's put the constitutional question aside for a moment. Although we have a strong disagreement about the scope of the problem, Professor Volokh and I agree that some employers are suppressing worker speech that is not restricted by hostile environment harassment law. This problem can only be resolved if those of us who care about workers-about their speech and about their right to equal treatment-join together to provide employers with more sophisticated and subtle advice about how to handle workplace harassment. If we can develop an approach that protects against unlawful discrimination but also is sensitive to free expression, we can substantially reduce any potential for

91. Klein Interview, supra note 85; see also Mary E. McGarry, The Ombudsman Privilege: Keeping Harassment Complaints Confidential, N.Y. L.J., Nov. 30, 1995, at 1.

92. See Epstein, supra note 2, at 402-08. Professor Volokh states that much of this data supports his claim of an erosion of the law's "severe or pervasive" requirement because it fails to note the frequency or intensity of the reported harassment. But in fact, the data demonstrate both that many respondents report being subjected to unwelcome sexual comments, and that they themselves typically do not consider such behavior to be "harassing" until it begins to occur as often as once a week. Telephone Interview with Freada Klein, President of Klein Associates, Inc. (Sept. 11, 1996).

93. Freada Klein, Current Complexities in Sexual Harassment: What Every Employer Should Know, ANDREws Sexual HaRassment Advisor, Nov. 1995 (less than 5\% report harassment); James E. Gruber, How Women Handle Sexual Harassment: A Literature Review, 74 Sociol. \& Social RES. 3, 5 (1989) (less than 10\% report harassment).

94. Klein Interview, supra note 85.

95. Working Women's Inst., Research Series Rep. No. 3, The Impact of SEXual Harassment on THE JoB: A PROFILE OF THE EXPERIENCES OF 92 WOMEN (1970).

96. See supra text accompanying notes $40-50$.

97. See Epstein, supra note 2, at $420-30$. 
chilling effect. ${ }^{98}$

What would such an approach look like? It would include an antiharassment policy that sets forth a clear definition of gender-based harassment and includes concrete examples that (1) illustrate the importance of context, (2) delineate which areas of the worksite are sufficiently private to allow a broader range of expression, and (3) help potential harassers to interpret the responses of their targeted audience so they can be sensitive to unwelcomeness. It would encourage complainants to come forward and discuss potential problems with designated human resource staff members, provide both informal (fully confidential) and formal complaint channels, and protect complainants from retaliation. It would create mechanisms to assess the frequency and severity of harassment, such as periodic workforce surveys and the establishment of a gender issues committee. ${ }^{99}$

Finally, a comprehensive, effective approach to the problem would provide workers and managers with in-depth training, so that potential harassers can learn that preventing gender-based harassment on the job is not just about conforming to the dictates of politically correct "feminazis." It's about whether women who want to earn a living have to endure severe forms of abuse and degradation from which their male counterparts are spared. It's about taking a necessary step toward integrating women into the American workplace.

98. The importance of this work transcends the constitutional debate. Title VII's prohibitions on job discrimination have led many employers to become increasingly familiar with data demonstrating that employee harassment results in substantial business costs through sick leave, decreased worker productivity, and loss of employees. See supra text accompanying note 4. "Corporations are beginning to realize that investment to minimize sexual harassment in the workplace can yield startling economic returns. . . . It is imperative that U.S. companies grasp an important fact: Great economic benefits can be derived from establishing and maintaining a harassment-free workplace." Crawford, supra note 4, at 35. It is increasingly possible that these employers may decide to adopt strict antiharassment policies even if the courts adopt arguments like those articulated by Professor Volokh and strike the law down on First Amendment grounds.

99. See, e.g., KLEIN Assocs., INC., A COMPREHENSIVE APPROACH [to sexual harassment] (1991). 